\title{
FORMULASI DAN AKTIVITAS GRANUL BIOLARVASIDA TEPUNG JINTAN HITAM
}

\author{
(Nigella sativa L.)
}

Formulation And Activity Of Black Cumin Flour (Nigella sativa L.) Biolarvicide Granules

\author{
Dwi Rachmawaty Daswi*, Arisanty \\ Jurusan Farmasi Politeknik Kesehatan Kemenkes Makassar \\ *Koresponden Email : $\underline{\text { dwialamsyah@gmail.com }}$
}

DOI: https://doi.org/10.32382/mf.v16i2.1653

\begin{abstract}
One of the efforts to eradicate and prevent the transmission of diseases is accomplished through vector control. Larvae eradication is a strategic key in vector control programs. Natural biolarvicide are made using traditional plants, such as black cumin (Nigella sativa L.). This study aims to formulate, test the physical quality as well as the activity of the black cumin flour biolarvicide granules. Similarly, the black cumin flour is obtained by grinding the cumin seeds to a fine degree of 30/40, then mixing it with fillers and a binder to form a biolarvicide granule preparation. The biolarvicide granule formulation of black cumin flour was prepared in 3 concentrations at 1\%, 5\% and 10\%. The biolarvicide preparations obtained were then tested for its physical quality and also its biolarvicide activity. Based on the results obtained, black cumin flour are formulated into biolarvicide granule dosage forms, all formulas meeting the requirements of a good physical quality test. Meanwhile, the biolarvicide activity test with a concentration of $10 \%$ showed that the average larvae that died within 24 hours was 9. This shows that black cumin flour (Nigella sativa L.) Likely to be used as a biolarvicide granule preparation (10\% concentration) with the same larval mortality results as abate positive control $(P>0.05)$.
\end{abstract}

Keywords : Biolarvicide Granules, Cumin Powder, Activity Test, Physical Quality Test

\section{ABSTRAK}

Salah satu upaya pemberantasan dan pencegahan penularan penyakit dapat dilakukan dengan pengendalian vektor. Pemberantasan larva merupakan kunci strategis program pengendalian vektor. Pembuatan biolarvasida alami dapat dilakukan dengan menggunakan tanaman tradisional salah satunya adalah jintan hitam (Nigella sativa L.). Tujuan dari penelitian ini adalah untuk memformulasi, menguji mutu fisik dan menguji aktivitas dari sediaan granul biolarvasida tepung jintan hitam. Tepung jintan hitam diperoleh dengan cara biji jintan hitam dihaluskan sesuai derajat halus 30/40 kemudian dicampurkan dengan bahan pengisi dan bahan pengikat untuk menjadi sediaan granul biolarvasida. Formulasi granul biolarvasida tepung jintan hitam ini dibuat dalam 3 konsentrasi yaitu konsentrasi 1\%, 5\% dan 10\%. Sediaan biolarvasida yang diperoleh kemudian diuji mutu fisiknya dan juga diuji aktivitas biolarvasidanya. Berdasarkan hasil yang diperoleh, tepung jintan hitam dapat diformulasikan ke dalam bentuk sediaan granul biolarvasida di mana semua formula memenuhi syarat uji mutu fisik yang baik, sedangkan untuk uji aktivitas biolarvasida konsentrasi $10 \%$ menunjukkan hasil larva yang mati rata-rata dalam waktu 24 jam yaitu sebanyak 9 larva. Hal ini menunjukkan bahwa tepung jintan hitam (Nigella sativa L.) sangat potensial digunakan sebagai sediaan granul biolarvasida (konsentrasi 10\%) dengan hasil kematian larva yang sama dengan kontrol positif abate ( $\mathrm{P}>0,05)$.

Kata kunci : Granul Biolarvasida, Tepung Jintan Hitam, Uji Aktivitas, Uji Mutu Fisik

\section{PENDAHULUAN}

Penyakit tular vektor sampai saat ini masih harus merndapatkan perhatian yang serius. Penyakit ini ditularkan dengan perantaraan vektor atau binatang pembawa penyakit. Penyakit tular vektor yang tingkat kejadiaannya masih cukup tinggi adalah malaria dan demam berdarah, di mana vektornya adalah nyamuk. Penyakit ini mendapatkan prioritas dalam pembangunan kesehatan karena berpotensi menyebabkan terjadinya kejadian luar biasa (KLB) dan memberikan kerugian ekonomi pada masyarakat.

Upaya pemberantasan dan pencegahan penularan penyakit malaria dan demam berdarah dapat dilakukan dengan pengendalian vektor dari penyakit tersebut. Upaya pengendalian vektor penyakit dapat dilakukan secara hayati berupa insektisida alami yaitu dengan memanfaatkan tanaman beracun terhadap serangga tetapi tidak mempunyai dampak terhadap lingkungan atau 
ramah lingkungan dan tidak berbahaya terhadap manusia. Insektisida alami aman digunakan karena mudah terdegradasi di alam sehingga tidak meninggalkan residu di tanah, air dan udara (Ningsi et al., 2016).

Pemberantasan larva ini merupakan kunci strategis program pengendalian vektor di seluruh dunia (Okumu et al., 2007 dalam Aradilla, 2009). Penggunaan insektisida sebagai larvasida secara umum dapat digunakan masyarakat untuk mengendalikan pertumbuhan vektor tersebut. Insektisida yang sering digunakan di Indonesia adalah abate. Penggunaan abate di Indonesia sudah sejak tahun 1976. Empat tahun kemudian, yakni tahun 1980, Temephos $1 \%$ b/v (abate) ditetapkan sebagai bagian dari program pemberantasan massal Aedes aegypti di Indonesia (Daniel, 2008). Meskipun begitu, penggunaan insektisida yang berulang dapat menambah resiko kontaminasi residu pestisida dalam air, terutama air minum (Andriana et al., 2012).

Berdasarkan kekurangan yang masih didapatkan dari pemakaian abate (Temephos), muncul ketertarikan untuk mengembangkan dan menggunakan biolarvasida yang alami, mudah didapatkan, serta aman bagi tubuh manusia dan lingkungan (Ndione et al., 2007 dalam Utami, 2016). Pembuatan biolarvasida alami bisa dengan cara menggunaan bahan yang berasal dari tumbuhan. Salah satu tumbuhan yang berpotensi menjadi biolarvasida adalah jintan hitam (Nigella sativa L.). Kandungan aktif dari biji jintan hitam diantaranya mengandung glukosida beracun melantin, zat pahit migeleon dan timokinon di mana timokinon menunjukkan efek antiproliferatif, induksi apotosis dan mengganggu potensial membran mitokondria (El Mahdi, 2005).

Senyawa flavonoid yang terkandung di jintan hitam (Nigella sativa L.) menyerang sistem pernafasan yang ada pada permukaan tubuh larva dan menimbulkan kelayuan saraf sehingga tidak mampu bernafas (Okumu et al., 2007 dalam Aradilla, 2009). Senyawa saponin akan mengganggu perkembangan dan gangguan pergantian kulit pada larva sehingga larva tidak akan mampu berkembang ke stadium selanjutnya (Chaieb, 2010 dalam Utami, 2016).

Beberapa hasil penelitian menunjukan bahwa sebagian besar tanaman yang mengandung minyak atsiri dan flavonoid memiliki daya proteksi terhadap hinggapan nyamuk. Insektisida dari tanaman mudah terurai (terdegradasi) di alam sehingga tidak meninggalkan residu di tanah, air dan udara. Selain itu insektisida nabati mempunyai tingkat keamanan yang lebih tinggi bila dibandingkan dengan menggunakan bahan kimia (Adebowale, 2006 dalam Ismail, 2017).

Jintan hitam (Nigella sativa L.) yang diekstrak dan dibuat pada konsentrasi $0,2 \% ; 0,4 \%$;
$0,6 \% ; 0,8 \%$ dan $1 \%$ diketahui efektif menghambat perkembangan larva nyamuk sebesar $95 \%$ (Purwoko, 2009). Namun penggunaan ekstrak dinilai kurang efektif dan efisien untuk digunakan karena penampakan visual yang kurang nyaman. Oleh karena itu, biji jintan hitam (Nigella sativa L.) dibuat formula dalam bentuk sediaan granul biolarvasida dengan menggunakan metode granulasi basah, di mana metode tersebut merupakan metode yang akan menghasilkan granul dengan ukuran yang lebih seragam dan spheris. Biji jintan hitam (Nigella sativa L.) yang diserbukkan kemudian dibuat dalam bentuk sediaan granul biolarvasida, ini juga merupakan terobosan baru mengingat selama ini penelitianpenelitian sebelumnya menggunakan ekstrak.

Berdasarkan uraian latar belakang di atas, maka permasalahan yang timbul adalah bagaimanakah kualitas mutu fisik dan aktivitas larvasida dari sediaan granul biolarvasida tepung jintan hitam (Nigella sativa L.)?

\section{METODE \\ Jenis Penelitian}

Penelitian ini merupakan penelitian eksperimental laboratorium yang dilakukan pada bulan Januari-September 2019 di Laboratorium Teknologi Farmasi, Jurusan Farmasi, Politeknik Kesehatan Makassar.

\section{Bahan Uji dan Sampel}

Bahan uji yang digunakan dalam penelitian ini adalah jintan hitam (Nigella sativa L.) sedangkan sampel dari penelitian ini adalah larva nyamuk.

\section{Alat dan Bahan}

Alat - alat yang digunakan yaitu bejana maserasi, pipet tetes, batang pengaduk, gelas ukur, gelas kimia, timbangan analitik, sieve shaker, heating dry oven, Erlenmeyer, 15 gelas plastik, pisau, corong, dan lumpang. Sedangkan bahanbahan yang digunakan antara lain tepung jintan hitam (Nigella sativa L.), larva nyamuk, etanol $96 \%$, kertas saring, aluminium foil, Na. CMC 2\%, laktosa dan air suling.

\section{Prosedur Kerja}

\section{Penyiapan alat}

Disiapkan 15 gelas plastik sebagai kontainer tempat penyimpanan larva nyamuk.

\section{Pengambilan dan pengelolaan bahan uji}

a. Pengambilan bahan uji

Bahan uji yang digunakan adalah jintan hitam (Nigella sativa L.).

b. Pengolahan bahan uji

Jintan hitam dicuci terlebih dahulu, kemudian diangin-anginkan hingga kering, setelah itu jintan hitam yang telah 
kering lalu dihaluskan dengan menggunakan blender sampai menjadi tepung.

\section{Rancangan formula}

Pada penelitian ini dibuat 3 formula granul dengan konsentrasi bahan uji 1\%;5\% dan $10 \%$ yang dibuat dengan metode granulasi basah. Pembuatan granul diawali dengan menimbang bahan-bahan yakni tepung jintan hitam, laktosa dan Na. CMC. Tepung jintan hitam kemudian dimasukkan ke dalam wadah lalu ditambahkan laktosa sebagai pengisi dan ditetesi larutan Na. CMC $2 \%$ sedikit demi sedikit sambil diaduk dan terbentuk massa yang kompak (dapat dikepal). Massa yang basah kemudian diayak menggunakan ayakan Mesh No. 18 hingga terbentuk granul yang basah. Selanjutnya granul dikeringkan di dalam lemari pengering pada suhu $40^{\circ} \mathrm{C}$ selama kurang lebih 2 jam hingga terbentuk granul kering. Granul kering yang diperoleh diayak kembali dengan menggunakan pengayak No. 20.

\section{Evaluasi Granul}

\section{a. Uji kadar air}

Timbang granul kering sebanyak 1 gram dan masukkan ke dalam kurs porselen yang telah dikeringkan. Setelah itu dimasukkan ke dalam oven pada suhu $105^{\circ} \mathrm{C}$ selama 1 jam, kemudian dinginkan dalam desikator dan ditimbang (Lachman, 1989).

\section{b. Uji kecepatan alir}

Aliran granul diuji dengan mengalirkan 25 g granul ke dalam flowmeter sampai granul melewati corong kemudian dicatat waktunya. Daya alir granul dihitung dengan perbandingan waktu dan massa granul habis melewati corong (Voight, 1995).

\section{c. Uji sudut istirahat}

Sudut istirahat ditentukan dengan memasukkan sejumlah massa granul ke dalam corong. Massa yang jatuh akan membentuk kerucut, lalu diukur tinggi dan diameter kerucut (Aulton, 2013).

\section{d. Distribusi ukuran partikel}

Sejumlah $25 \mathrm{~g}$ granul ditimbang dan dimasukkan ke dalam penyayak bertingkat yang memiliki panci penampung dan penutup yang sesuai. Pengayak digetarkan dengan gelombang elektromagnetik selama 5 menit. Ditetapkan jumlah persentase yang tertinggal dalam setiap dasar ayakan melalui timbangan (Aulton, 2013).

\section{e. Uji waktu terdispersi granul}

Ditimbang lebih kurang 400 mg granul, dituang ke dalam gelas lalu ditambahkan ke dalamnya air kurang lebih satu liter, diaduk sampai terdispersi sempurna lalu dicatat waktu yang dibutuhkan sampai terdispersi (Siregar, 2010 ).

\section{Pengujian aktivitas}

Setiap percobaan menggunakan 15 wadah. 9 wadah sebagai wadah eksperimen dan 6 wadah sebagai kontrol positif dan negatif. Setiap wadah berisi 10 ekor jentik nyamuk. Dilakukan 3 kali pengulangan untuk memenuhi jumlah sampel yang diperlukan. Percobaan dilakukan dengan mencampurkan $1 \mathrm{~g}$ granul yang mengandung tepung jintan hitam (Nigella sativa L.) ke dalam wadah eksperimen kemudian diobservasi pada 30 menit, 1 jam, 12 jam dan 24 jam.

\section{HASIL}

Berdasarkan hasil penelitian yang dilakukan, dapat dilihat bahwa sediaan yang dibuat terdiri dari tiga formula granul biolarvasida dengan konsentrasi zat aktif yaitu tepung jintan hitam (Nigella sativa L.) yang berbeda-beda yakni $1 \% ; 5 \%$ dan $10 \%$. Hasil uji mutu fisik meliputi uji kadar air, uji kecepatan alir, uji sudut istirahat, distribusi ukuran aprtikel, uji waktu terdispersi granul dan juga pengujian aktivitas sediaan granul biolarvasida terhadap larva nyamuk.

\section{Evaluasi Granul}

a. Uji Kadar Air

\begin{tabular}{ccc}
\hline No. & Formula & $\begin{array}{c}\text { \% Kadar } \\
\text { Air }\end{array}$ \\
\hline $\mathbf{1}$ & $\begin{array}{c}\text { I (Tepung Jintan Hitam } \\
\text { 1\%) }\end{array}$ & 1,43 \\
\hline $\mathbf{2}$ & $\begin{array}{c}\text { II (Tepung Jintan } \\
\text { Hitam 5\%) }\end{array}$ & 3,73 \\
\hline $\mathbf{3}$ & III (Tepung Jintan & 2,8 \\
& Hitam 10\%) & \\
\hline
\end{tabular}

Kadar air dinyatakan sebagai MC (Moisture Content) yakni sekitar 2\%-3\%. Pada uji kadar air diperoleh hasil persentase kadar air semua formula berkisar dari 1,43\%-3,73\% (Lachman, 1989).

b. Uji Kecepatan Alir

\begin{tabular}{ccc}
\hline No & Formula & $\begin{array}{c}\text { Kecepatan alir } \\
\text { (g/detik) }\end{array}$ \\
\hline $\mathbf{1}$ & $\begin{array}{c}\text { I(Tepung Jintan } \\
\text { Hitam 1\%) }\end{array}$ & 7,46 \\
\hline $\mathbf{2}$ & $\begin{array}{c}\text { II (Tepung Jintan } \\
\text { Hitam 5\%) }\end{array}$ & 8,19 \\
\hline $\mathbf{3}$ & $\begin{array}{c}\text { III (Tepung Jintan } \\
\text { Hitam 10\%) }\end{array}$ & 6,70 \\
& & \\
\hline
\end{tabular}

Pada uji kecepatan alir diperoleh hasil bahwa semua formula memenuhi persyaratan kecepatan alir yaitu pada rentang 4-10g/detik atau bersifat mudah mengalir (Voight, 1995). 
c. Uji Sudut Istirahat

\begin{tabular}{ccc}
\hline No & Formula & $\begin{array}{c}\text { Sudut } \\
\text { istirahat }\left({ }^{\mathbf{0}}\right)\end{array}$ \\
\hline $\mathbf{1}$ & $\begin{array}{c}\text { I(Tepung Jintan } \\
\text { Hitam 1\%) }\end{array}$ & 18,26 \\
& II (Tepung Jintan \\
Hitam 5\%) & 19,79 \\
\hline $\mathbf{3}$ & III (Tepung Jintan & 20,30 \\
& Hitam 10\%) & \\
\hline
\end{tabular}

Pada uji sudut istirahat menunjukkan hasil bahwa semua formula memiliki kriteria sudut istirahat yang memenuhi persyaratan yaitu $5-35^{0}$ (Aulton, 2013).

d. Uji Distribusi Ukuran Partikel

\begin{tabular}{cccc}
\hline No & Formula & Mesh (No.) & $\begin{array}{c}\text { Berat } \\
\text { Granul } \\
\text { (Gram) }\end{array}$ \\
\hline $\mathbf{1}$ & $\begin{array}{c}\text { I (Tepung Jintan } \\
\text { Hitam 1\%) }\end{array}$ & 18 & 0,14 \\
& & 20 & 2,70 \\
\cline { 3 - 4 } & & 40 & 15,55 \\
\cline { 3 - 4 } & & 60 & 1,71 \\
\cline { 3 - 4 } & & 100 & 1,22 \\
\hline \multirow{2}{*}{} & II (Tepung Jintan & 18 & 0,16 \\
& Hitam 5\%) & & 1,33 \\
\cline { 3 - 4 } & & 20 & 16,64 \\
\cline { 3 - 4 } & & 60 & 1,89 \\
\cline { 3 - 4 } & & 100 & 1,34 \\
& & &
\end{tabular}

\begin{tabular}{ccc}
\hline 3 & III (Tepung Jintan \\
Hitam 10\%) & 18 & 0,30 \\
\hline & 20 & 1,55 \\
\cline { 2 - 3 } & 40 & 15,73 \\
\cline { 2 - 3 } & 60 & 1,89 \\
\cline { 2 - 3 } & 100 & 1,29 \\
\hline
\end{tabular}

Hasil distribusi ukuran partikel pada semua formula menunjukkan bahwa granul yang dihasilkan adalah serbuk granul agak kasar karena sebagian besar granul tidak dapat melewati ayakan Mesh No. 40 (Yunita et al., 2017).

e. Uji Waktu Terdispersi Granul

\begin{tabular}{ccc}
\hline No & Formula & $\begin{array}{c}\text { Waktu } \\
\text { terdispersi } \\
\text { ( Menit })\end{array}$ \\
\hline $\mathbf{1}$ & $\begin{array}{c}\text { I (Tepung Jintan } \\
\text { Hitam 1\%) }\end{array}$ & 2,42 \\
\hline $\mathbf{2}$ & $\begin{array}{c}\text { II (Tepung Jintan } \\
\text { Hitam 5\%) }\end{array}$ & 1,26 \\
\hline $\mathbf{3}$ & $\begin{array}{c}\text { III (Tepung Jintan } \\
\text { Hitam 10\%) }\end{array}$ & 2,02 \\
&
\end{tabular}

Hasil uji waktu terdispersi granul menunjukkan bahwa semua formula memenuhi persyaratan waktu terdispersi granul, yakni kurang dari 5 menit (Siregar, 2010).

2. Uji Aktivitas Granul Biolarvasida Tepung Jintan Hitam (Nigella sativa L.)

\begin{tabular}{lccccc}
\hline \multirow{2}{*}{ WAKTU } & KONTROL & KONTROL & FI & F2 & F3 \\
& POSITIF & NEGATIF & (Tepung Jintan & (Tepung Jintan & (Tepung Jintan \\
& (ABATE) & (Tanpa Tepung & Hitam 1\%) & Hitam 5\%) & Hitam 10\%)
\end{tabular}

\begin{tabular}{|c|c|c|c|c|c|c|c|c|c|c|c|c|c|c|c|}
\hline \multicolumn{16}{|c|}{ Jintan Hitam) } \\
\hline & 1 & 2 & 3 & 1 & 2 & 3 & 1 & 2 & 3 & 1 & 2 & 3 & 1 & 2 & 3 \\
\hline 30 menit & 2 & 2 & 2 & - & - & - & - & - & - & 1 & 1 & 1 & 2 & 1 & 1 \\
\hline 1 jam & 9 & 9 & 9 & - & - & - & - & - & - & 2 & 1 & 1 & 5 & 4 & 3 \\
\hline 6 jam & 9 & 9 & 10 & - & - & - & - & - & - & 5 & 7 & 5 & 8 & 8 & 7 \\
\hline 12 jam & 9 & 9 & 10 & - & - & - & 2 & - & - & 8 & 8 & 7 & 9 & 9 & 9 \\
\hline 24 jam & 9 & 9 & 10 & - & - & - & - & - & - & 8 & 8 & 9 & 9 & 9 & 9 \\
\hline Rata-rata & \multicolumn{3}{|c|}{9} & \multicolumn{3}{|c|}{0} & \multicolumn{3}{|c|}{1} & \multicolumn{3}{|c|}{8} & \multicolumn{3}{|c|}{9} \\
\hline
\end{tabular}

Berdasarkan penelitian yang dilakukan, hasil uji aktivitas biolarvasida tepung jintan hitam (Nigella sativa L.) menunjukkan hasil untuk konsentrasi $1 \%$ jumlah rata-rata larva nyamuk yang mati setelah 24 jam adalah 1 ekor, untuk konsentrasi $5 \%$ jumlah rata-rata nyamuk yang mati setelah 24 jam adalah 8 ekor dan untuk konsentrasi $10 \%$ jumlah ratarata nyamuk yang mati adalah 9 ekor. 


\section{PEMBAHASAN}

Pada penelitian ini telah dibuat granul biolarvasida dengan menggunakan bahan aktif tepung jintan hitam (Nigella sativa L.). Hal ini didasari karena tepung jintan hitam (Nigella sativa L.) mengandung zat aktif glukosida beracun melantin, zat pahit migeleon dan timokinon di mana timokinon menunjukkan efek antiproliferatif, induksi apotosis dan menggangu potensial membran mitokondria (El Mahdi, 2005). Senyawa flavonoid yang terkandung di jintan hitam (Nigella sativa L.) menyerang sistem pernafasan yang ada pada permukaan tubuh larva dan menimbulkan kelayuan syaraf sehingga tidak mampu bernafas Okumu et al., 2007 dalam Aradilla, 2009). Penelitian ini menggunakan Na. CMC sebagai pengikat dan menggunakan Laktosum sebagai pengisi.

Sediaan granul biolarvasida tepung jintan hitam (Nigella sativa L.) ini dilakukan beberapa pengujian mutu fisik dengan parameter-parameter yang diukur yaitu : pengujian kadar air, pengujian kecepatan alir, pengujian sudut istirahat, pengujian distribusi ukuran partikel dan pengujian waktu terdispersi granul. Pengujian aktivitas granul biolarvasida tepung jintan hitam (Nigella sativa L.) juga dilakukan terhadap larva nyamuk. Granul biolarvasida tepung jintan hitam (Nigella sativa L.) dikatakan memenuhi syarat mutu fisik yang baik apabila memenuhi persyaratan yang telah ditetapkan dan dikatakan aktif terhadap larva nyamuk apabila dapat membunuh larva nyamuk dalam jumlah yang sama atau hampir sama dengan kontrol positif.

Pengujian kadar air sediaan granul biolarvasida tepung jintan hitam (Nigella sativa L.) diperoleh hasil persentase kadar air untuk formula 1 yaitu sebesar $1,43 \%$; untuk formula 2 sebesar $3,73 \%$ dan untuk formula 3 sebesar $2,8 \%$. Untuk formula 1 dan formula 3 hasil yang ditunjukkan memenuhi persyaratan kadar air yang telah ditetapkan yaitu berkisar antara 2-3\% sedangkan untuk formula 2 tidak memenuhi persyaratan. Hilangnya air dalam granul saat proses pengeringan bertujuan untuk menjamin stabilitas dan pengawetan yang efektif. Semakin kecil kadar air yang dihasilkan maka akan semakin memperbaiki kualitas granul biolarvasida yang dihasilkan.

Pengujian kecepatan alir sediaan granul biolarvasida tepung jintan hitam (Nigella sativa L.) diperoleh hasil, untuk formula 1 kecepatan alirnya yaitu 7,46 g/dtk, untuk formula 2 kecepatan alirnya yaitu $8,19 \mathrm{~g} / \mathrm{dtk}$ dan untuk formula 3 kecepatan alirnya $6,70 \mathrm{~g} / \mathrm{dtk}$. Hal ini menunjukkan bahwa hasil yang diperoleh untuk semua formula memenuhi persyaratan kecepatan alir yaitu pada rentang 4-10 g/dtk atau bersifat mudah mengalir. Pengujian sifat alir granul sangat penting untuk dilakukan karena berperan penting dalam homogenitas dosis pada saat pengemasan granul. Sifat alir yang baik dapat membuat bobot granul yang mengalir pada pengisian kemasan akan seragam sehingga dosis setiap kemasan juga akan seragam.

Pengujian sudut istirahat sediaan granul biolarvasida tepung jintan hitam (Nigella sativa L.) menunjukkan hasil yang diperoleh bahwa semua formula memiliki kriteria sudut istirahat yang sesuai persyaratan yang telah ditetapkan yaitu rentang antara $5-35^{\circ}$. formula 1 memiliki sudut istirahat $18,26^{0}$; formula 2 memiliki sudut istirahat $19,79^{\circ}$ dan formula 3 memiliki sudut istirahat $20,30^{\circ}$.

Pengujian distribusi ukuran partikel sediaan granul biolarvasida tepung jintan hitam (Nigella sativa L.) menunjukkan hasil bahwa semua formula merupakan granul biolarvasida yang memiliki sifat agak kasar karena sebagian besar granul tidak dapat melewati pengayak No. 40. Pada formula 1 granul yang tidak bisa melewati ayakan No. 40 sebesar 14,55 gram, untuk formula 2 granul yang tidak bisa melewati ayakan No. 40 sebesar 16,64 gram dan untuk formula 3 granul yang tidak bisa melewati ayakan No. 40 sebesar 15,73 gram.

Pengujian waktu terdispersi granul biolarvasida tepung jintan hitam (Nigella sativa L.) diperoleh hasil bahwa semua formula memenuhi persyaratan waktu terdispersi granul, yakni kurang dari 5 menit. Pada formula 1 waktu terdispersi granul yaitu sebesar 2 menit 41 detik, untuk formula 2 waktu terdispersi granul yaitu sebesar 1 menit 26 detik dan untuk formula 3 waktu terdispersi granul yaitu sebesar 2 menit 2 detik.

Pengujian aktivitas granul biolarvasida tepung jintan hitam (Nigella sativa L.) terhadap larva nyamuk terlihat bahwa pada konsentrasi terendah granul biolarvasida tepung jintan hitam (Nigella sativa L.) yaitu $1 \% \mathrm{~b} / \mathrm{v}$ menyebabkan kematian paling sedikit yaitu dengan nilai rata-rata mencapai 1 ekor nyamuk selama 24 jam, sedangkan jumlah kematian larva nyamuk tertinggi dijumpai pada konsentrasi $10 \% \mathrm{~b} / \mathrm{v}$ dengan nilai rata-rata mencapai 9 ekor nyamuk. Hal ini menunjukkan bahwa semakin tinggi konsentrasi dari tepung jintan hitam (Nigella sativa L.) maka semakin banyak menyebabkan kematian pada larva nyamuk, hal tersebut sejalan dengan penelitian yang dilakukan oleh Purwoko (2009) yang menyebutkan semakin tinggi konsentrasi maka semakin tinggi pula kematian larva terutama di 24 jam pertama, di mana penelitian tersebut menyatakan untuk konsentrasi $1 \%$ ekstrak etanol biji jintan hitam (Nigella sativa L.) menyebabkan kematian larva nyamuk sebesar 96\%. Juga pada penelitian Yunita et al (2017) yang 
menggunakan granul biolarvasida dari ekstrak daun jeruk nipis juga menyatakan semakin tinggi konsentrasi maka kematian larvasida semakin besar di mana kematian larvasida mencapai 76,7\% untuk konsentrasi $15 \%$ ekstrak daun jeruk nipis.

Dengan demikian granul biolarvasida tepung jintan hitam (Nigella sativa L.) bersifat aktif membunuh larvasida. Hal ini disebabkan karena kandungan dari tepung jintan hitam (Nigella sativa L.) yaitu glikosida beracun, melantin, juga mengandung zat pahit migeleon dan timokinon yang menunjukkan efek antiproliferatif, induksi apotosis dan menggangu potensial membran mitokondria (El Mahdi, 2005). Kandungan zat aktif dalam jintan hitam (Nigella sativa L.) bersifat antifeedant yang berarti larva kehilangan selera makan, selain itu juga bersifat racun saraf dan mengganggu produksi ekdison. Zat aktif dari jintan hitam (Nigella sativa L.) yang masuk secara perlahan melalui seluruh permukaan tubuh larva akan menyebabkan aktivitas menurun, lemah dan tidak mampu berkembang ke stadium lebih lanjut (Purwoko, 2009).

Tepung jintan hitam (Nigella sativa L.) juga mengandung flavonoid yang merupakan racun pernafasan masuk kedalam tubuh larva melalui sistem pernafasan yang kemudian akan menimbulkan gangguan pada syaraf dan kerusakan pada sistem pernafasan sehingga mengakibatkan larva tidak dapat bernafas dan akhirnya menyebabkan kematian larva. Selain itu senyawa aktif pada tepung jintan hitam (Nigella sativa L.) yang berperan sebagai larvasida adalah saponin yang berfungsi sebagai racun perut atau racun pencernaan. Cara kerja saponin adalah menurunkan tegangan permukaan selaput mukosa traktus digestivus larva sehingga menjadi korosif. Saponin juga menyebabkan kerusakan pada jaringan epithelium pada usus tengah larva sehingga gagal mengabsorbsi sari-sari makanan yang seharusnya diedarkan melalui haemolimfe. Terhambatnya proses absorbsi sari-sari makanan mengakibatkan proses pertumbuhan pada larva terhambat dan akhirnya menyebabakan kematian larva (Saraswati et al., 2014). Namun kelemahan dari penelitian ini adalah tidak menentukan jenis larva nyamuk yang digunakan untuk penelitian sehingga tidak diketahui jenis larva nyamuk yang mati akibat granul biolarvasida jintan hitam (Nigella sativa L.) ini.

Pada uji Statistic Test of Normality, pengujian ini dilakukan untuk melihat normalitas dari masing-masing perlakuan di mana hasil yang diperoleh $\mathrm{P}=0,000 \leq 0,05$ sehingga dapat disimpulkan bahwa hasilnya tidak normal. Pada pengelolaan data Statistic Test of Homogenity of Variances untuk melihat homogenitas sampel, di mana hasil yang diperoleh adalah $\mathrm{P}=0,002 \leq 0,05$ yang menunjukkan bahwa hasil tersebut tidak homogen.

Selanjutnya karena diperoleh hasil yang tidak normal dan tidak homogen, maka pengujian dilanjutkan dengan uji Non-Parametric Kruskall Wallis Test untuk melihat perbedaan antar semua perlakuan dan diperoleh hasil $\mathrm{P}=0,013 \leq 0,05$ yang berarti signifikan atau ada perbedaan nyata antar semua perlakuan. Setelah itu pengujian dilanjutkan dengan uji Mann-Whitney Test untuk melihat perbedaan antar perlakuan, dan dari hasil Mann-Whitney Test ini, menunjukkan bahwa konsentrasi $5 \%$ dan $10 \%$ tidak berbeda nyata dari kontrol positif (abate) dengan nilai $\mathrm{P}>0,05$. Dari hasil statistik menunjukkan konsentrasi yang paling potensial sebagai granul biolarvasida adalah konsentrasi $10 \%$ dengan jumlah kematian larva nyamuk terbanyak di bandingkan dengan konsentrasi yang lain.

\section{KESIMPULAN}

Berdasarkan hasil penelitian yang dilakukan, maka dapat disimpulkan bahwa sediaan granul biolarvasida tepung jintan hitam (Nigella sativa $\mathrm{L}$.) konsentrasi 1\%; $5 \%$ dan $10 \%$ memenuhi persyaratan uji mutu fisik meliputi uji kadar air, uji kecepatan alir, uji sudut istirahat, uji distribusi ukuran partikel dan uji waktu terdispersi dan mempunyai aktivitas larvasida terutama untuk konsentrasi $10 \%$ dengan nilai $\mathrm{P}>0.05$ yang tidak berbeda nyata dengan kontrol positif (abate).

\section{SARAN}

Berdasarkan hasil penelitian yang
dilakukan, maka mengaplikasikan granul biolarvasida tepung jintan hitam (Nigella sativa L.) di masyarakat sebagai salah satu alternatif insektisida alami.

\section{DAFTAR PUSTAKA}

Andriana, A., Hamidah, \& Moehammadi, N. (2013). Uji Efektivitas Ekstrak Kulit Buah Jeruk Purut (Citrus hystrix D.C) dan Jeruk Kalamondin (Citrus mitis Blanco) sebagai Biolarvasida Nyamuk Aedes aegypti L. Jurnal Ilmiah Biologi FST, 1(1).

Aradilla, S. . (2009). Uji Efektivitas Larvasida Ekstrak Ethanol Daun Mimba ( Azadirachta indica) terhadap Larva Aedes aegypti. Skripsi Universitas Dipenogoro Semarang.

Aulton, M., and Summers M., 2013. Tablet and Compaction. In: Pharmaceutics The Science of Dosage Form Design, 4th. Philadelphia: Churchill Livingstone.

Daniel, 2008. Ketika Larva dan Nyamuk Dewasa Sudah Kebal Terhadap Insektisida. Farmacia.Vol.7 
El-Mahdy MA, Zhu Q, Wang QE, Wani G, Wani AA. 2005. Thymoquinone induces apoptosis through activation of caspase- 8 and mitochondrial events in p53-null myeloblastic leukemia HL-60 cells. Int $J$ Cancer. 2005 Nov 10;117(3):409-17. doi: 10.1002/ijc.21205. PMID: 15906362.

Ismail, Asep. 2017. Efektivitas Ekstrak Daun Jeruk Limau Sebagai Penolak Nyamuk Ae.Aegypti Di Laboratorium Kementerian Kesehatan Loka Litbang P2B2 Batu Raja Palembang :Skripsi Palembang

Lachman, L., Lieberman, H. A., \& Kaning, J. L. (2008). Teori dan Praktek Farmasi Industri Edisi III. In Universitas Indonesia, Jakarta. https://doi.org/10.1016/S222218081260149-2

Purwoko, A. E., \& Hidayati, T.2009. Pengaruh Ekstrak-Etanol Biji Jinten hitam (Nigella sativa L.) terhadap Mortalitas Larva Aedes aegypti The Infuence of Blackcumin seed ( Nigella sativa L .) Ethanolic extract on Aedes aegypti larvae mortality. Mutiara Medica Vol 9 (2), 23-28.

Saraswati, A. P., Endah, S., \& Ellyzarti. (2014).
Uji Potensi Ekstrak Daun Pepaya (Carica papaya L.) Sebagai Larvasida Terhadap Larva Nyamuk Aedes aegypti Instar III. Prosiding Seminar Nasional Pengembangan Teknologi Pertanian Polinela, 278-284.

Siregar, C.J.P. dan Wikarsa, S., 2010, Teknologi Farmasi Sediaan Tablet Dasar-Dasar Praktis, Buku Kedokteran EGC, Jakarta.

Utami, R., M., 2016. Perbandingan Antara Pengaruh Air Perasan Kulit Jeruk Purut (Citrus hystrix) Dan Abate (Temephos) Terhadap Tingkat Kematian Larva Aedes Aegypti Skripsi Universitas Andalas Padang.

Yunita, M., Michrun, N., Nurul, F., Sriwanti, L., Rannu, Muhammad, A., \& Febi, R. D. 2017. Efek Biolarvasida Nyamuk Aedes aegypti dari Granul Ekstrak Daun Jeruk Nipis (Citrus aurantifolia. Jurnal Ilmiah Manuntung, 3(2), 116-121.

Voigt. 1995. Buku Pelajaran Teknologi Farmasi. Universitas Gajah Mada Press.https://doi.org/10.1016/j.jiph.2015.01 .007 